\title{
Histamine content in rennet ripening cheeses during storage at different temperatures and times
}

\author{
Anna Madejska, Mirosław Michalski, \\ Marzena Pawul-Gruba, Jacek Osek \\ Department of Hygiene of Food of Animal Origin \\ National Veterinary Research Institute, 24-100 Pulawy, Poland \\ josek@piwet.pulawy.pl \\ Received: October 31, 2017 \\ Accepted: February 26, 2018
}

\begin{abstract}
Introduction: In recent years, there has been a great interest in biogenic amines such histamine, as they are associated with the quality and safety of some kinds of fermented foods. The aim of this study was to evaluate the effect of temperature and storage time on the content of histamine in cheeses. Material and Methods: Samples of mould and hard cheeses were examined with RP-HPLC with an organic-aqueous mobile phase containing acidic buffer and chaotropic salt. The samples were stored either at $22 \pm 2{ }^{\circ} \mathrm{C}$ for 42 days (mould and hard cheeses) or at $4 \pm 2{ }^{\circ} \mathrm{C}$ for 112 days (mould cheeses) and 133 days (hard cheeses). Results: The mean total histamine content in cheeses stored at $22^{\circ} \mathrm{C}$ was higher than the content in those stored at $4{ }^{\circ} \mathrm{C}$, with the highest concentrations found in Gorgonzola Piccante cheese $(730.47 \mathrm{mg} / \mathrm{kg})$. Histamine concentration in some types of cheeses exceeded the toxic threshold dose, indicating that after long or inadequately cool storage they may not be safe for consumers. Conclusion: To protect cheeses from contamination with histamine-producing bacteria and to safeguard consumers from poisoning, factors conducive to this amine's formation should be minimised during cheese processing. Suitable temperature and time during storage of cheeses are recommended to avoid the intoxication. Monitoring of this toxin in food is necessary to ensure safety of consumers.
\end{abstract}

Keywords: histamine, cheeses, HPLC-DAD, storage conditions, health risk.

\section{Introduction}

Histamine is a heterocyclic biogenic amine which can be formed in a large variety of types of food of animal origin, particularly in fish and cheeses. Histamine is a product of decarboxylation of histidine in a reaction, catalysed by bacterial decarboxylase (5, 32). Cheeses are a favourable environment for the formation of this amine due to the presence of free amino acids and microorganisms releasing decarboxylases $(4,19)$. Histamine production in cheeses can be influenced by many factors, e.g. the type of bacterial starter culture, cheese $\mathrm{pH}$, salt concentration, contamination during production process, storage temperature, and ripening time (16, 24, 27, 30). The most common bacterial species responsible for production of histamine are: Morganella morganii, Photobacterium psychrotolerans, Photobacterium phosphoreum,
Lactobacillus casei, Klebsiella pneumoniae, Enterobacter aerogenes, and Hafnia alvei (14, 17, 25). The highest amount of histamine is produced during the ripening of cheeses, when proteins are degraded to free amino acids including histidine $(6,9,24,31)$.

Cheeses are one of the most common products responsible for histamine poisoning in humans $(11,23)$. This intoxication manifests itself in headaches, hypotension, vomiting, diarrhoea, cramping, skin rashes and swellings (3). Histamine is degraded in the body by oxidative deamination catalysed by monoamine and diamine oxidases $(21,26)$. However, after ingestion of food with high concentrations of histamine, in the absence or scarcity of these enzymes (e.g. due to genetic factors, allergy, or ingested alcohol) the detoxification system is unable to eliminate histamine sufficiently $(3,15)$.

In 1967 the first report was made of histamine poisoning after consumption of Gouda cheese with 
histamine in the range of $850-1,870 \mathrm{mg} / \mathrm{kg}$ (8). Other literature data reported histamine levels in cheeses up to $2,500 \mathrm{mg} / \mathrm{kg}(3,10)$.

The provisions of European Union regulations specify a permissible level of histamine only for fish and fish products (7). Currently, there are no established criteria relating to the level of this amine in cheeses. The aim of this study was to determine the histamine content in hard and mould cheeses stored at different temperatures and time periods.

\section{Material and Methods}

Sample collection. Four types of mould cheese (Lazur Blue, Président Brie Natural, Camembert Erival, and Gorgonzola Piccante) and two types of hard cheese (Salami, Mlekdamer) from various local shops in the eastern region of Poland were investigated. Each kind of cheese sample was divided into two equal portions and one part was stored at $4 \pm 2{ }^{\circ} \mathrm{C}$ for up to 112 (mould cheeses) and 133 days (hard cheeses) and the other was kept at room temperature of $22 \pm 2{ }^{\circ} \mathrm{C}$ for up to 42 days. After a suitable storage period, a piece of cheese (200 g) was homogenised and analysed. All cheeses were tested for histamine content immediately after delivery to the laboratory (day 0). Mould cheeses were then examined on days 14,28 , and 42 of storage at room temperature and on days $28,56,84$, and 112 if stored at $4 \pm 2{ }^{\circ} \mathrm{C}$. Hard cheeses were additionally tested at day 35 of storage at room temperature and on days 91 and 133 if stored at $4 \pm 2{ }^{\circ} \mathrm{C}$. For each type of cheese the experiments were performed in triplicates.

Reagents. All reagents used were HPLC or analytical grade. Histamine dihydrochloride and 1-octanesulphonic acid were obtained from Acros Organics (Belgium). Trichloroacetic acid (TCA), potassium dihydrogen phosphate, orthophosphoric acid, and methanol were purchased from POCh (Poland). Polimeric weak anion solid phase extraction (SPE) cartridges (200 mg, $3 \mathrm{~mL}$ ) were sourced from Phenomenex (USA) and nylon syringe filters $(0.45 \mu \mathrm{m})$ were procured from Agilent Technology (USA). Water was purified using the Milli-Q system (Millipore Sigma, USA).

Histamine stock standard solution $(10 \mathrm{~g} / \mathrm{L})$ was prepared by dissolving of $828 \pm 0.1 \mathrm{mg}$ of histamine dihydrochloride in $50 \mathrm{~mL}$ of deionised water and storing the solution at $2-8^{\circ} \mathrm{C}$ for up to one month. Working standard solutions for the calibration curve were prepared on the day of analysis by appropriate dilutions of the stock in phosphate buffer $(0.01 \mathrm{M}$, $\mathrm{pH} 3.0)$.

Extraction of histamine from cheese samples and clean-up. Cheese samples of weight $10 \pm 0.01 \mathrm{~g}$ were weighed in a $50 \mathrm{~mL}$ polypropylene centrifuge tube. A total of $25 \mathrm{~mL}$ of TCA $(0.2 \mathrm{M})$ was added and the sample was mixed by vortexing for $2 \mathrm{~min}$, centrifuged for $10 \mathrm{~min}$ at $4,000 \times \mathrm{g}$ at $15^{\circ} \mathrm{C}$, and kept at $\leq-18^{\circ} \mathrm{C}$ for $30 \mathrm{~min}$. The upper lipid layer was discarded and $5 \mathrm{~mL}$ of the supernatant was transferred into a $10 \mathrm{~mL}$ flask which was filled up with deionised water. The sample was filtered through a $0.45 \mu \mathrm{m}$ nylon syringe filter into a glass tube and then cleaned up by SPE apparatus (J.T. Baker, USA) using polimeric weak anion SPE cartridges. The cartridges had previously been conditioned with $5 \mathrm{~mL}$ of methanol and then with $10 \mathrm{~mL}$ of phosphate buffer $(0.01 \mathrm{M}$, $\mathrm{pH}$ 3.0). Seven millilitres of the extract was transferred to the SPE column and passed through the cartridge into a $10 \mathrm{~mL}$ flask. Afterwards, the column was washed with $2 \mathrm{~mL}$ of phosphate buffer. The eluate was supplemented to $10 \mathrm{~mL}$ with phosphate buffer.

HPLC-DAD conditions and validation parameters. The content of histamine was analysed by high performance liquid chromatography using the Pro Star system (Varian, Netherlands) equipped with a diode array detector, quaternary pump, autosampler, and column thermostat, and controlled by the Galaxie Workstation software (Varian). The chromatographic separation was performed on a Unisol C18 column of $150 \times 4.6 \mathrm{~mm}$, particle size $3 \mu \mathrm{m}$, connected to a C18 precolumn of $10 \times 3 \mathrm{~mm}$ (Agela Technologies, USA). The mobile phase, consisting of $15 \%$ methanol in $0.1 \mathrm{M}$ potassium dihydrogen phosphate $(150 / 850, \mathrm{v} / \mathrm{v})$ with $1.6 \mathrm{mM}$ 1-octanesulphonic acid, was applied under isocratic conditions. The column oven temperature was maintained at $25^{\circ} \mathrm{C}$, the flow rate at $0.5 \mathrm{~mL} / \mathrm{min}$, and the injection volume was $20 \mu \mathrm{L}$. The UV detection was monitored at $215 \mathrm{~nm}$.

The range of the method for hard cheeses was $4.25-420 \mathrm{mg} / \mathrm{kg}$ and the limits of detection and quantification were $3.52 \mathrm{mg} / \mathrm{kg}$ and $4.25 \mathrm{mg} / \mathrm{kg}$ respectively, whereas the range of the method for mould cheeses was $7.13-420 \mathrm{mg} / \mathrm{kg}$ and the limits of detection and quantification were $6.27 \mathrm{mg} / \mathrm{kg}$ and $7.13 \mathrm{mg} / \mathrm{kg}$ respectively. The repeatability $(\mathrm{n}=6)$ and the reproducibility $(n=18)$ for hard cheeses were $3.6 \%$ and $4.6 \%$ respectively, whereas for mould cheeses these parameters were $1.9 \%$ and $3.0 \%$. Recovery of the method ranged from $80.1 \%$ for hard cheeses to $82 \%$ for mould cheeses.

\section{Results}

Histamine content in mould cheeses. The histamine content in mould cheeses is presented in Figs 1 and 2 as the mean \pm SD of three replicates. The results show changes in the amine formation during storage at different temperatures and time. The highest amount of histamine $(730.47 \pm 20.01 \mathrm{mg} / \mathrm{kg})$ was identified in Gorgonzola Piccante cheese stored for 42 days at room temperature (Fig. 1). In Camembert Erival cheese kept at $4^{\circ} \mathrm{C}$, histamine was detected at a high level $(405.21 \pm 30.06 \mathrm{mg} / \mathrm{kg})$ at the end of the storage period (112 days). In Gorgonzola Piccante cheese stored at $22^{\circ} \mathrm{C}$ and in Camembert Erival kept at $4{ }^{\circ} \mathrm{C}$, an 
increase in the amount of histamine was observed with the extended period of storage. Besides the Italian Gorgonzola Piccante and French Camembert Erival cheeses, other ambient-stored cheeses showed a slight increase in histamine content up to $40.49 \pm 18.29 \mathrm{mg} / \mathrm{kg}$
(Président Brie Natural cheese) and $10.85 \pm 3.97 \mathrm{mg} / \mathrm{kg}$ (Lazur Blue cheese) after 42 days of storage. With storage over 42 days at $22^{\circ} \mathrm{C}$, the average concentration of histamine was more than twofold higher than that found in cheeses stored at $4^{\circ} \mathrm{C}$ for 112 days.

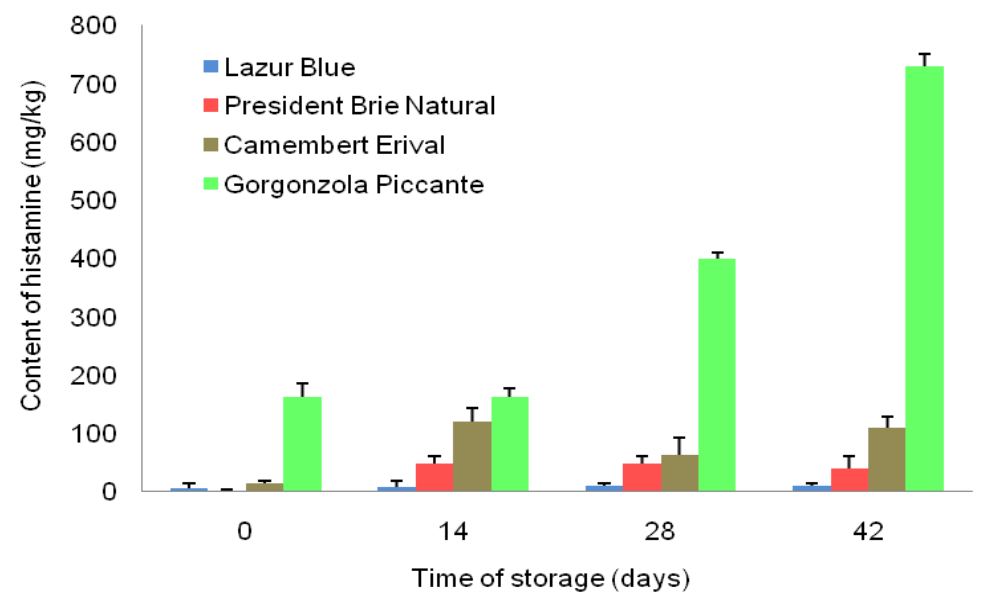

Fig. 1. Concentration of histamine in mould cheeses during storage at $22 \pm 2{ }^{\circ} \mathrm{C}$. Each bar represents results as mean $\pm \mathrm{SD}$

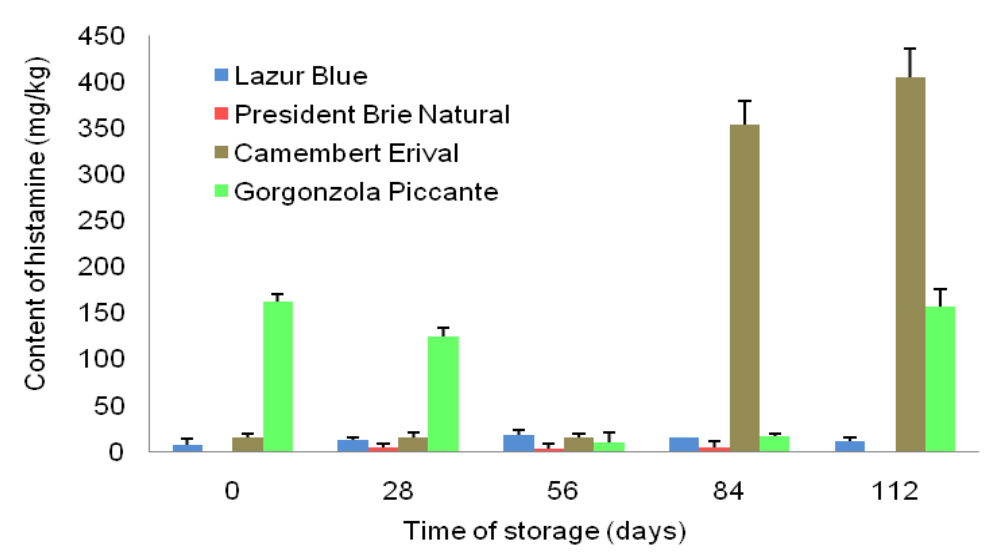

Fig. 2. Concentration of histamine in mould cheeses during storage at $4 \pm 2{ }^{\circ} \mathrm{C}$. Each bar represents results as mean $\pm \mathrm{SD}$

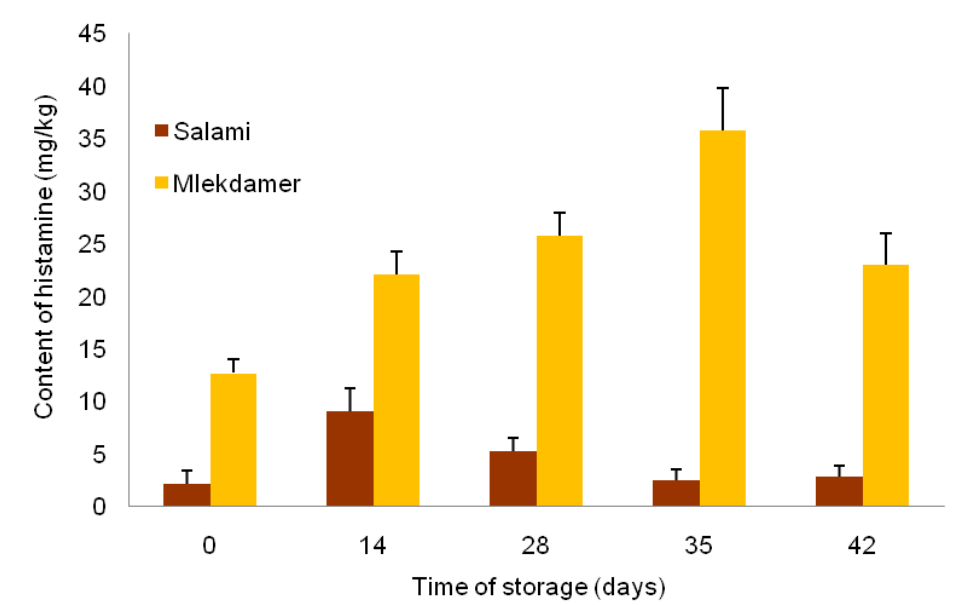

Fig. 3. Concentration of histamine in hard cheeses during storage at $22 \pm 2^{\circ} \mathrm{C}$. Each bar represents results as mean $\pm \mathrm{SD}$ of three replicates 


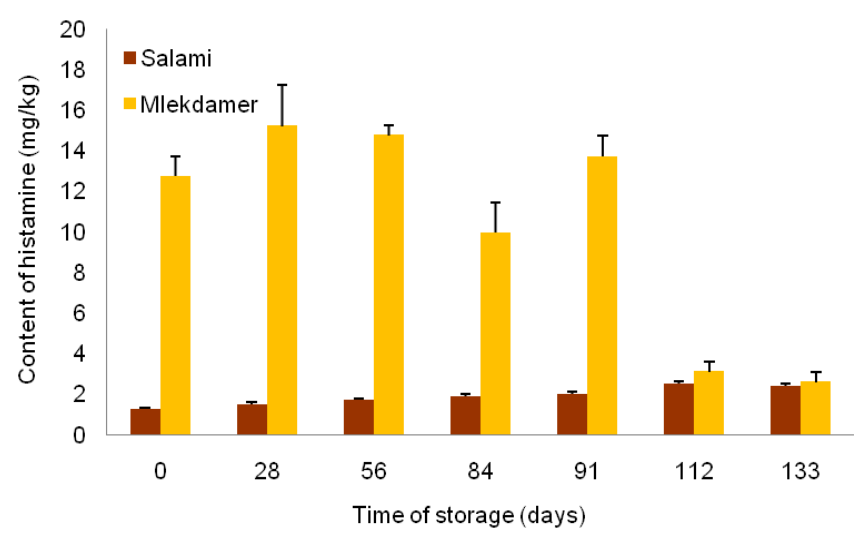

Fig. 4. Concentration of histamine in hard cheeses during storage at $4 \pm 2{ }^{\circ} \mathrm{C}$. Each bar represents results as mean \pm SD of three replicates

Histamine content in hard cheeses. The analysis of histamine presence in hard cheeses revealed that it was highest in Mlekdamer cheese after 35 days of storage at room temperature $(35.84 \pm 4.12 \mathrm{mg} / \mathrm{kg})$ (Fig. 3). Histamine concentration in this cheese ranged from 10 to $15 \mathrm{mg} / \mathrm{kg}$ during the 91 days of storage at $4 \pm 2^{\circ} \mathrm{C}$ and decreased after 112 days (Fig. 4). In Salami cheese the amine was found only in small amounts in samples stored at room temperature, and in samples stored at $4 \pm 2^{\circ} \mathrm{C}$ it was below the limit of detection of $3.52 \mathrm{mg} / \mathrm{kg}$. Storage over 42 days at $22^{\circ} \mathrm{C}$ resulted in the average concentration of histamine being more than twofold higher than the level found after storage at $4^{\circ} \mathrm{C}$ for 133 days.

\section{Discussion}

Histamine content in Gorgonzola cheese at the beginning of the study (day 0) was $162.63 \pm 23.57$ $\mathrm{mg} / \mathrm{kg}$, which may suggest improper storage conditions during ripening or manufacture of the cheese from raw material with a significant amount of histamine. The ripening and storage periods are considered one of the key factors influencing histamine production $(4,8,11$, 32). During that time, a marked change in texture and flavour occur which is mainly associated with enzymatic degradation of casein resulting in steady increase in free amino acids. Some of the amino acids are subjected to a further breakdown reaction as decarboxylation catalysed by bacterial decarboxylases, which gives rise to the formation of carbon dioxide and histamine (11). Thus, cheese could be considered an ideal environment for this amine production through bacterial decarboxylation of histidine.

Given that the toxic threshold dose for histamine in cheeses has been temporarily established at $400 \mathrm{mg} / \mathrm{kg}$ (29), it was found that the amine content exceeded this value in Gorgonzola cheese after 28 and 42 days of storage at $22^{\circ} \mathrm{C}$, where its levels reached $400.29 \pm 10.13$ and $730.47 \pm 20.01 \mathrm{mg} / \mathrm{kg}$, respectively, and reached this toxicity level in Camembert cheese on day 112 stored at $4^{\circ} \mathrm{C}(405.21 \pm 30.06 \mathrm{mg} / \mathrm{kg})$. The wide variability of histamine concentration in different cheeses may depend on type of cheese, ripening time, conditions of manufacturing process, and bacterial starter culture used $(16,20,21)$. In the present study less histamine was detected in hard cheeses than soft ones and its amount was low (in a range from below the limit of detection to $35.84 \pm 4.12 \mathrm{mg} / \mathrm{kg}$ ). This may be caused by soft cheeses' additional active microflora content (for example moulds) which is very active in transforming histidine to histamine. In none of the tested samples among hard cheeses was histamine concentration found to exceed the limit proposed by Rauscher-Gaberning et al. (29), which may indicate that these cheeses were safe for consumers.

The total histamine content in cheeses kept at $22^{\circ} \mathrm{C}$ was twofold higher than that kept at $4^{\circ} \mathrm{C}$. This result may support the opinion that storage temperature has a great influence on histamine concentrations, and the production of this amine is promoted at room temperature. This finding may be linked to the effect of temperature of $22 \pm 2{ }^{\circ} \mathrm{C}$ on some factors which influenced the biogenic amines formation such as microbial growth and enzymatic activity $(4,11)$.

The results of many studies have shown that the level of biogenic amines, including histamine, increased with storage time but also significantly depended on the temperature $(1,2,12,22)$. The histamine content was studied in traditional Czech curd cheese (Olomoucké tvarůžky) stored several weeks at different temperatures $\left(5^{\circ} \mathrm{C}\right.$ and $\left.20^{\circ} \mathrm{C}\right)$. This amine was detected in amounts of $74-411 \mathrm{mg} / \mathrm{kg}$ and its level increased throughout the storage period and at $20^{\circ} \mathrm{C}$ as compared to $5^{\circ} \mathrm{C}(32)$. El-Kosi et al. (11) studied the effect of time (7 to 120 days) and temperature $\left(7^{\circ} \mathrm{C}, 22^{\circ} \mathrm{C}\right.$, and $\left.32^{\circ} \mathrm{C}\right)$ on the content of histamine in traditional Egyptian cheese varieties. Their results confirmed the theory of the stimulating effects of long storage time and higher temperatures on histamine level. The effects of storage conditions on histamine content were also tested in other Egyptian cheeses and in them likewise the accumulation of histamine increased remarkably in the ripening and storage periods (13). The growth of biogenic amines during production and storage may also occur in 
unripened cheeses. In 12-day, $25^{\circ} \mathrm{C}$-stored Mexican queso chihuahua white cheese an increased content of biogenic amines was observed (histamine up to $452 \mathrm{mg} / \mathrm{kg}$ ) (28). Budak et al. (4) noted that histamine concentration reached the level of $265.5 \mathrm{mg} / \mathrm{kg}$ after 90 days' ripening at $10^{\circ} \mathrm{C}$ and it was detected in an amount higher than those of other biogenic amines in the Turkish white cheese samples investigated.

The results of the current investigation showed that histamine level did not always increase linearly during storage of cheeses. This finding may indicate that the formation of histamine in cheese depends on complex factors accelerating or retarding the production of this amine such as different numbers of decarboxylating microorganisms in certain parts of the cheese and internal microenvironmental conditions (access to $\mathrm{O}_{2}$ or effects caused by water) $(18,22)$.

Conflict of Interests Statement: The authors declare that there is no conflict of interests regarding the publication of this article.

Financial Disclosure Statement: This study was supported by the Polish Ministry of Science and Higher Education within the statutory activity of the Institute.

Animal Rights Statement: None required.

\section{References}

1. Aliakbarlu J., Alizadeh M., Razavi-Rohani S.M., Vahabzade Z., Saei S.S., Agh N.: Effects of processing factors on biogenic amines production in Iranian white Brine cheese. Res J Biol Sci 2009, 4, 23-28.

2. Andiç S., Tunçtürk Y., Javidipour I., Gençelep H.: Effects of different herbs on biogenic amine contents and some characteristics of Herby cheese. GIDA 2015, 40, 1-8.

3. Bodmer S., Imark C., Kneubuhl M.: Biogenic amines in foods. Histamine and food processing. Inflamm Res 1999, 48, 296-300.

4. Budak G.N.F., Karahan A.G., Çakmakçı M.L.: Factors affecting histamine and tyramine formation in Turkish White Cheese. Hacettepe J Biol Chem 2008, 36, 197-206.

5. Calzada J., del Olmo A., Picón A., Gaya P., Nuñez M.: Reducing biogenic-amine-producing bacteria, decarboxylase activity, and biogenic amines in raw milk cheese by high-pressure treatments. Appl Environ Microbiol 2013, 79, 1277-1283.

6. Calzada J., del Olmo A., Picón A., Nuñez M.: Proteolysis and biogenic amine buildup in high-pressure treated ovine milk blueveined cheese. J Dairy Sci 2013, 96, 4816-4829.

7. Commission Regulation (EC) No. 2073/2005 of 15 November 2005 on microbiological criteria for foodstuffs. Official J, L 338, 12.

8. Doeglas H.M.G., Huisman J., Nater J.P.: Histamine intoxication after cheese. Lancet 1967, 2, 1361-1362.

9. Durlu-Özkaya F., Ayhal K., Özkan G.: Biogenic amines determination in Tulum cheese by high performance liquid chromatography (HPLC). Milchwissenschaft 2000, 55, 27-28.

10. Ekici K., Coskun H., Sienkiewicz T.: Histamine formation and its control in cheese: A review. J Food Technol 2005, 3, 60-63.

11. El-Kosi O.H.R., Abdel-Hakiem E.H., Ayesh A.M., Mohamed J.I.I.: Effect of different storage temperatures and periods on biogenic amine formation in Ras cheese. Suez Canal Vet Med J 2009, 1, 207-219.
12. El-Zahar K.M.: Biogenic amines and microbiological profile of Egyptian cheeses. Univ J Food Nutr Sci 2014, 2, 18-26.

13. El-Zahar K.M., El-Zaher A.M.A., Ramadan M.F.: Levels of biogenic amines in cheeses and their impact on biochemical and histological parameters in rats. J Korean Soc Appl Biol Chem 2014, 57, 73-81.

14. Emborg J., Dalgaard P., Ahrens P.: Morganella psychrotolerans sp. nov., a histamine-producing bacterium isolated from various seafoods. Int J System Evolut Microbiol 2006, 56, 2473-2479.

15. Ercan S.S., Bozkurt H., Soysal C.: Significance of biogenic amines in foods and their reduction methods. J Food Sci Eng 2013, 3, 395-410.

16. Karovičová J., Kohajdová Z.: Biogenic amines in food. Chem Papers 2005, 59, 70-79.

17. Kim S.H., Gigry B., Barros B., Price R.G.: Histamine and biogenic amines production by $M$. morganii isolated form temperature abused albacore. J Food Prot 2000, 63, 244-251.

18. Komprda T., Smělá D., Novická K., Kalhotka L., Šustová K., Pechová P.: Content and distribution of biogenic amines in Dutchtype hard cheese. Food Chem 2007, 102, 129-137.

19. Kung H.F., Tsai Y.H., Hwang C.C., Lee Y.H., Hwang J.H., Wei C.I., Hwang D.F.: Hygienic quality and incidence of histamine-forming Lactobacillus species in natural and processed cheese in Taiwan. J Food Drug Anal 2005, 13, 51-56.

20. Macku I., Lazarkova Z., Buoka F., Hrabi J.: Biogenic amine content in mould cheese during storage. Ecol Chem Eng A 2009, $12,1592-1597$.

21. Madejska A., Michalski M., Osek J.: Biogenic amines in rennet ripening cheeses as a health risk to consumers. Med Weter 2017, 73, 214-219.

22. Marijan A., Džaja P., Bogdanović T., Škoko I., Cvetnić Ž., Dobranić V., Zdolec N., Šatrović E., Deverin K.: Influence of ripening time on the amount of certain biogenic amines in rind and core of cow milk Livno cheese. Mljekarstvo 2014, 64, 159-169.

23. Novella-Rodríguez S., Veciana-Nogués M.T., IzquierdoPulido M., Vidal-Carou M.C.: Distribution of biogenic amines and polyamines in cheese. J Food Sci 2003, 68, 750-755.

24. O’Brien N.M., O’Connor T.P., Callaghan J.O., Dobson A.D.W.: Toxins in cheese. In: Cheese Chemistry, Physics and Microbiology, Fox P.F., McSweeney P.L.H., Cogan T.M., Guinee T.P. (eds), London 2004, pp. 561-571.

25. Paleologos E.K., Savvaidis I.N., Kontominas M.G.: Biogenic amines formation and its relations to microbiological and sensory attributes in ice-stored whole, gutted, and filleted Mediterranean Sea bass (Dicentrarchus labrax). Food Microbiol 2004, 21, 549-557.

26. Pawul M., Michalski M., Osek J.: Histamine - occurrence, detection, and health risk to consumers. Med Weter 2013, 69, 466-470.

27. Pinho O., Ferreira I.M.P.L.V.O., Mendes E., Oliveira B.M., Ferreira M.: Effect of temperature on evolution of free amino acid and biogenic amine contents during storage of Azeitão cheese. Food Chem 2001, 75, 287-291.

28. Rak L.: Biogenic amines in dairy products. Med Weter 2005, 61, 391-393.

29. Rauscher-Gabernig E., Grossgut R., Bauer F., Paulsen P.: Assessment of alimentary histamine exposure of consumers in Austria and development of tolerable levels in typical foods. Food Control 2009, 20, 423-429.

30. Roig-Sagués A.X., Molina A.P., Hernández-Herrero M.M.: Histamine and tyramine forming microorganisms in Spanish traditional cheeses. Eur Food Res Technol 2002, 215, 96-100.

31. Schirone M., Tofalo R., Visciano P., Corsetti A., Suzzi G.: Biogenic amines in Italian Pecorino cheese. Front Microbiol 2012, 3, 1-9.

32. Standarová E., Vorlová L., Kordiovská P., Janštová B., Dračková M., Borkovcová I.: Biogenic amine production in Olomouc curd cheese (Olomoucké tvarůžky) at various storage conditions. Acta Vet Brno 2010, 79, 147-156. 